\title{
Infiltration with ropivacaine plus lornoxicam reduc- es postoperative pain and opioid consumption
}

\author{
[L'infiltration avec de la ropivacaine, plus du lornoxicam, réduit la douleur \\ postopératoire et la consommation d'opioïdes]
}

Beyhan Karamanlioglu MD, ${ }^{*}$ Alparslan Turan MD, ${ }^{*}$ Dilek Memis MD, ${ }^{*}$ Gaye Kaya MD, ${ }^{*}$ Sanem Ozata MD, * Mevlut Ture MD†

Purpose: To compare efficacy and patient outcome of wound infiltration with ropivacaine, lornoxicam, or their combination for control of pain following thyroid surgery.

Methods: Eighty patients underwent thyroid surgery were randomly assigned to one of four groups. Before skin closure, local tissues were infiltrated with $12 \mathrm{~mL}$ saline in Group S, with $10 \mathrm{~mL}$ of ropivacaine $0.75 \%$ plus $2 \mathrm{~mL}$ saline in Group $\mathrm{R}$, with $2 \mathrm{~mL}$ of lornoxicam (8 mg) plus $10 \mathrm{~mL}$ saline in Group $\mathrm{L}$, and with $10 \mathrm{~mL}$ ropivacaine $0.75 \%$ plus $2 \mathrm{~mL}$ lornoxicam $(8 \mathrm{mg})$ in Group RL. Pain scores, total and incremental meperidine consumption were recorded at $30 \mathrm{~min}$, one, two, three, four, six, eight, 12, 18, and $24 \mathrm{hr}$ postoperatively. Time to first analgesic requirement, patient satisfaction, and duration of hospital stay were also compared after surgery.

Results: The pain scores in Group RL were significantly lower in the first $12 \mathrm{hr}$ than in Group S, and in the first four hours than in Groups $R$ and $L(P<0.01)$. The time to first analgesic requirement was significantly longer $(14.8 \pm 8.4 \mathrm{hr}$ vs $5.9 \pm$ $5.2 \mathrm{hr} ; P<0.0 \mathrm{l})$, the total pethidine consumption was significantly less than Group S $(34.0 \pm 33.0 \mathrm{mg}$ vs $78.0 \pm 29.8 \mathrm{mg}$; $P<0.00 \mathrm{I})$, return of gastrointestinal function, ambulation time, length of hospital stay $(P<0.05)$ were significantly shorter, and patient satisfaction $(P<0.01)$ was significantly better in Group RL than in Group $S(P<0.05)$.

Conclusion: Wound infiltration with ropivacaine $0.75 \%$ plus lornoxicam $8 \mathrm{mg}$ combination improved postoperative pain control and patient comfort, and decreased the need for opioids than the use of either drug alone.
Objectif : Comparer l'efficacité d'une infiltration avec de la ropivacaïne, du lornoxicam ou leur combinaison après une opération de la thyroïde et comparer l'évolution des patients.

Méthode : Des patients devant être opérés à la thyroïde (80) ont été répartis en quatre groupes. Avant la fermeture cutanée, les tissus locaux ont été infiltrés avec $12 \mathrm{~mL}$ de solution saline dans le groupe $S, 10 \mathrm{~mL}$ de ropivacaïne à $0,75 \%$ plus $2 \mathrm{~mL}$ de solution saline dans le groupe $R, 2 \mathrm{~mL}$ de lornoxicam $(8 \mathrm{mg}$ ) plus $10 \mathrm{~mL}$ de solution saline dans le groupe $L$ et $10 \mathrm{~mL}$ de ropivacaïne à $0,75 \%$ plus $2 \mathrm{~mL}$ de lornoxicam (8 $\mathrm{mg}$ ) dans le groupe RL. Les scores de douleur et la consommation totale et incrémentielle de mépéridine ont été notés à $30 \mathrm{~min}$, puis à une, deux, trois, quatre, six huit, 12, 18 et $24 \mathrm{~h}$ après l'opération. Le moment de la première demande d'analgésique, la satisfaction du patient et la longueur du séjour ont été comparés.

Résultats : Les scores de douleurs ont été significativement plus bas chez les patients du groupe RL que chez ceux du groupe $S$ pendant les 12 premières heures et que chez ceux des groupes $R$ et $L$ pendant les quatre premières heures $(P<0,01)$. Le moment de la première demande d'analgésique a été plus tardif (I 4,8 $\pm 8,4 \mathrm{~h}$ vs 5,9 $\pm 5,2 \mathrm{~h} ; \mathrm{P}<0,0 \mathrm{l})$, la consommation totale de péthidine $a$ été plus basse que dans le groupe $S(34,0 \pm 33,0 \mathrm{mg}$ vs 78,0 \pm $29,8 \mathrm{mg} ; P<0,00 \mathrm{l}$ ), le retour de la fonction gastro-intestinale et de la marche a été plus précoce, la longueur du séjour hospitalier $(P<0,05)$ plus courte et la satisfaction des patients $(P<0,01)$ meilleure dans le groupe $R L$ que dans le groupe $S(P<0,05)$.

Conclusion : L'infiltration dans le site d'incision avec une combinaison de ropivacaïne à $0,75 \%$ et de $8 \mathrm{mg}$ de lornoxicam a amélioré le contrôle postopératoire de la douleur et le confort des patients et a diminué les besoins d'opiödes par rapport à l'usage d'un seul médicament.

From the Departments of Anesthesiology, ${ }^{*}$ and Biostatistics, $†$ Trakya University, Medical Faculty, Edirne, Turkey.

Address correspondence to: Dr. Beyhan Karamanlioglu, Trakya Üniversitesi Tip Fakültesi, Anesteziyolojive Reanimasyon AD, 22030,

Edirne, Turkey. Fax: +9028423580 96; E-mail: beykar@mynet.com

Support was provided solely from institutional and/or departmental sources.

Accepted for publication May 26, 2005.

Revision accepted July 18, 2005. 
$\mathrm{T}$ HYROID surgery induces brief postoperative pain, requiring analgesia/therapy during the first day after thyroid surgery. Post-thyroidectomy pain has frequently been treated with nonsteroidal anti-inflammatory drugs (NSAIDs) or opioids. ${ }^{1,2}$ Lornoxicam is a potent new NSAID of the oxicam class that has been shown to be effective and well tolerated in the treatment of postoperative pain. ${ }^{3-5}$ The short plasma half-life (three to five hours) of lornoxicam may provide advantages over other NSAIDs. ${ }^{4}$

Wound infiltration with local anesthetics is an alternative and acceptable method for the management of postoperative pain. ${ }^{6,7}$ The main limitation of wound infiltration is that only long-acting local anesthetics produce effective and sufficient duration of analgesia. Bupivacaine is the most preferred longacting local anesthetic and has been used successfully for local infiltration after surgery. ${ }^{8,9}$ However, large doses of bupivacaine are relatively toxic, and moderate plasma concentrations can cause catastrophic cardiotoxicity. ${ }^{10}$ Ropivacaine, a long-acting amide local anesthetic, is chemically related to bupivacaine but it has less cardiac and central nervous system toxicity. ${ }^{11}$ It produces cutaneous vasoconstriction that restricts systemic absorption of the drug and increases its local duration of action. ${ }^{12}$ Moreover, ropivacaine possesses anti-inflammatory activity that may further reduce pain when administered locally. ${ }^{13}$

The analgesic synergy of NSAID-local anestheticopioid combination was demonstrated by Visalyaputra et $a l^{14}$ In a recent study, postoperative wound infiltration with levobupivacaine plus lornoxicam provided better postoperative pain relief than levobupivacaine alone after cholecystectomy. ${ }^{15}$ Further studies are needed to evaluate the analgesic efficacy of wound infiltration with another regimen of ropivacaine enriched with the NSAID lornoxicam alone on acute pain with different postoperative pain models. We therefore designed, a prospective, randomized, double-blinded, placebo-controlled study, to compare the effect of ropivacaine, lornoxicam or their combination on analgesia efficacy and patient outcome after thyroid surgery.

\section{Methods}

After obtaining the approval of the Institutional Ethics Committee (Trakya University, Edirne, Turkey) and written informed consent from the patients, we studied 80 patients, American Society of Anesthesiologists physical status I and II, undergoing elective partial or total thyroidectomy, in a prospective, randomized, double-blinded, placebo-controlled protocol. All patients were physiologically euthyroid. Exclusion criteria included a known allergy, sensitivity, or contraindication to opioids, local anesthetic or any NSAID, renal or liver failure, a history of peptic ulcer, a history of asthma, clotting disorder, an intrathoracic goiter, and pregnancy. In addition, patients who had previously suffered from a difficult endotracheal intubation (more than two attempts at tracheal intubation) at the induction of anesthesia were also excluded.

Patients were randomly divided into four groups of 20 patients each. For premedication, midazolam 0.07 $\mathrm{mg} \cdot \mathrm{kg}^{-1}$ was administered im $45 \mathrm{~min}$ before the surgical procedure. In the operating room, a crystalloid infusion was started, and mean arterial blood pressure (MAP), heart rate (HR), and peripheral oxygen saturation were monitored (Cato PM 8040; Dräger, Lübeck, Germany). After the administration of oxygen, anesthesia was induced with propofol $\left(2 \mathrm{mg} \cdot \mathrm{kg}^{-1}\right.$ $i v)$ and fentanyl $\left(2 \mu \mathrm{g} \cdot \mathrm{kg}^{-1} \mathrm{iv}\right)$. Tracheal intubation was facilitated with atracurium $\left(0.6 \mathrm{mg} \cdot \mathrm{kg}^{-1} i v\right)$. Anesthesia was maintained with 1 to $2.5 \%$ (inspired concentration) sevoflurane and $66 \%$ nitrous oxide in oxygen. Additional fentanyl boluses up to $0.2 \mathrm{mg}$ iv were allowed during surgery. Ventilation was controlled mechanically (Cato; Dräger, Lübeck, Germany), and adjusted to maintain end-expiratory carbon dioxide between 34 to $36 \mathrm{mmHg}$. Muscle relaxation was maintained with atracurium $\left(0.1 \mathrm{mg} \cdot \mathrm{kg}^{-1}\right.$ iv $)$ boluses as required.

At the end of surgery and before skin closure, would infiltration was performed by the surgeon, who was blinded to the applied drug solution. The patients were allocated by computer randomization to receive: (Group S) $12 \mathrm{~mL}$ of normal saline; (Group R) 10 $\mathrm{mL}$ of ropivacaine $0.75 \%$ (Naropin $^{\circledR}$; AstraZeneca, Milano, Italy) with $2 \mathrm{~mL}$ of normal saline; (Group L) $2 \mathrm{~mL}(8 \mathrm{mg})$ of lornoxicam $\left(4 \mathrm{mg} \cdot \mathrm{mL}^{-1}\right)$, (Xefo ${ }^{\circledR}$; Nycomed Pharma AS, Roskilde, Denmark) with 10 $\mathrm{mL}$ of normal saline; (Group RL) $10 \mathrm{~mL}$ of ropivacaine $0.75 \%$ with $2 \mathrm{~mL}(8 \mathrm{mg}$ ) of lornoxicam. The thyroid surgery was performed with patients in the supine position, with the head slightly hyperextended. At the completion of the surgery, neostigmine (1.5 $\mathrm{mg} i v)$ and atropine $(0.5 \mathrm{mg} i v)$ were administered for reversal of the residual paralysis, and the trachea was extubated.

After tracheal extubation, patients were transferred to the postanesthesia care unit. Assessment of postoperative pain was made on the basis of the visual analogue scale (VAS) where $0=$ 'no pain' and 10 = 'worst pain imaginable'. Degree of sedation was determined according to a sedation score ranging from 0 to $2(0=$ alert, $1=$ drowsy but rousable to 
TABLE I Demographic characteristics, and surgical data of patients

\begin{tabular}{lllll}
\hline Variable & $\begin{array}{l}\text { Group } S \\
(n=20)\end{array}$ & $\begin{array}{l}\text { Group } R \\
(n=20)\end{array}$ & $\begin{array}{l}\text { Group } L \\
(n=20)\end{array}$ & $\begin{array}{l}\text { Group RL } \\
(n=20)\end{array}$ \\
\hline Age (yr) & $48 \pm 15$ & $51 \pm 16$ & $49 \pm 15$ & $46 \pm 14$ \\
Weight (kg) & $79 \pm 21$ & $76 \pm 17$ & $78 \pm 19$ & $75 \pm 16$ \\
ASA physical status (I/II/III) & $7 / 11 / 2$ & $7 / 12 / 1$ & $8 / 11 / 1$ & $8 / 11 / 1$ \\
Gender (female/male) & $15 / 5$ & $14 / 6$ & $15 / 5$ & $13 / 7$ \\
Duration of anesthesia (min) & $170 \pm 35$ & $163 \pm 33$ & $166 \pm 34$ & $168 \pm 35$ \\
Duration of operation (min) & $153 \pm 29$ & $148 \pm 30$ & $150 \pm 30$ & $152 \pm 31$ \\
Unilateral/bilateral lobectomy & $4 / 16$ & $5 / 15$ & $4 / 16$ & $3 / 17$ \\
\hline
\end{tabular}

Group $\mathrm{S}=12 \mathrm{~mL}$ saline; Group $\mathrm{R}=10 \mathrm{~mL}$ of ropivacaine $0.75 \%$ plus $2 \mathrm{~mL}$ saline; Group $\mathrm{L}=2 \mathrm{~mL}$ of lornoxicam $(8 \mathrm{mg})$ plus $10 \mathrm{~mL}$ saline; Group RL $=10 \mathrm{~mL}$ ropivacaine $0.75 \%$ plus $2 \mathrm{~mL}$ lornoxicam $(8 \mathrm{mg})$. ASA = American Society of Anesthesiologists. Values are number $(\mathrm{n})$ or mean \pm standard deviation. No statistical difference was found among the groups.

voice, 2 = very drowsy, rousable to shaking). The VAS scores, MAP, HR, respiratory rate, and sedation scores were assessed at one, two, three, four, six, eight, 12, and $24 \mathrm{hr}$ after surgery. The total and incremental meperidine requirement at these times, and the time to first analgesic need were determined according to VAS; when VAS > 4, pethidine $1 \mathrm{mg} \cdot \mathrm{kg}^{-1} i m$ was administered and noted. The first analgesic need was regarded as the time elapsed between the administration of the study drugs and the administration of an analgesic. On patient request or if postoperative nausea and vomiting (PONV) occurred, ondansetron $8 \mathrm{mg} i v$ was given. The number of patients receiving antiemetics and doses in patients receiving antiemetics were recorded. Patients were assessed for return of gastrointestinal function twice daily by a physician who systematically questioned the patients and consulted nurse observations for the time until return of bowel sounds, time of the first flatus and time of the oral intake. Time of being able to walk unassisted (ambulation) was also assessed after surgery. After 24 $\mathrm{hr}$, satisfaction with the analgesia was evaluated using a four-point scale $(0=$ poor; 1 = satisfactory; 2 = good; $3=$ excellent). In addition, patients were questioned about the occurrence of any adverse effects during the first $24 \mathrm{hr}$, and adverse effects were recorded. All data were recorded by the same anesthesia resident who was blinded to the study drugs administered.

Every $24 \mathrm{hr}$ after the operation, patients were assessed as ready or not ready for discharge from hospital, by four discharge criteria: 1) normal defecation and no urinary retention: yes/no; 2) able to mobilize and dress: yes/no; 3 ) need for opioid: yes/no; 4) surgical complication requiring patient hospitalization: yes/no. When the patient scored yes on the two former, and no on the latter questions, they were considered ready for discharge from hospital. ${ }^{16}$ Then, the length of stay (LOS) in hospital was recorded.

\section{Statistical analysis}

Descriptive statistics are expressed as mean \pm standard deviation (SD) unless otherwise stated. All continuous variables were tested for normal distribution by the Kolmogorov-Smirnov test. One way ANOVA was used for normally distributed variables. The Bonferroni post-hoc tests were applied to determine the significance of differences in means. Kruskal-Wallis ANOVA was used for non-normally distributed data. If a significant result was obtained, Kruskal-Wallis $\mathrm{Z}$ test was performed for multiple comparisons. Categorical data were analyzed using Chi-square or Fisher's exact test, as appropriate. A value of $P<0.05$ was considered statistically significant. Data were analyzed using NCSS 2001 for Windows (NCSS, Kaysville, UT, USA). According to a power analysis for VAS scores in patients, we calculated that 20 patients in each group would be required to demonstrate a maximum difference $=1.6(\mathrm{SD}=1.7)$ among groups $(\alpha=0.05, \beta=0.2)$.

\section{Results}

Eighty patients were enrolled in the study, 20 in each group. The four groups were comparable with respect to demographic and surgery data (Table I). There were no differences in the HR, MAP, respiratory rate, and sedation scores (data not shown) between the groups at any time during the first $24 \mathrm{hr}$ after surgery.

As shown in Figure 1, pain scores during the first $12 \mathrm{hr}$ postoperatively were significantly lower in the Group RL compared with the Group $S(P<0.01)$. Additionally, pain scores were significantly lower in the Group RL compared with the Groups R and L during the first four hours postoperatively $(P<0.01)$. Pain scores were significantly lower in the Groups $R$ and $\mathrm{L}$ compared with the Group $\mathrm{S}$ during the first six and eight hours $(P<0.01, P<0.01 ; P<0.05$, $P<0.05$, respectively). The incremental meperidine 


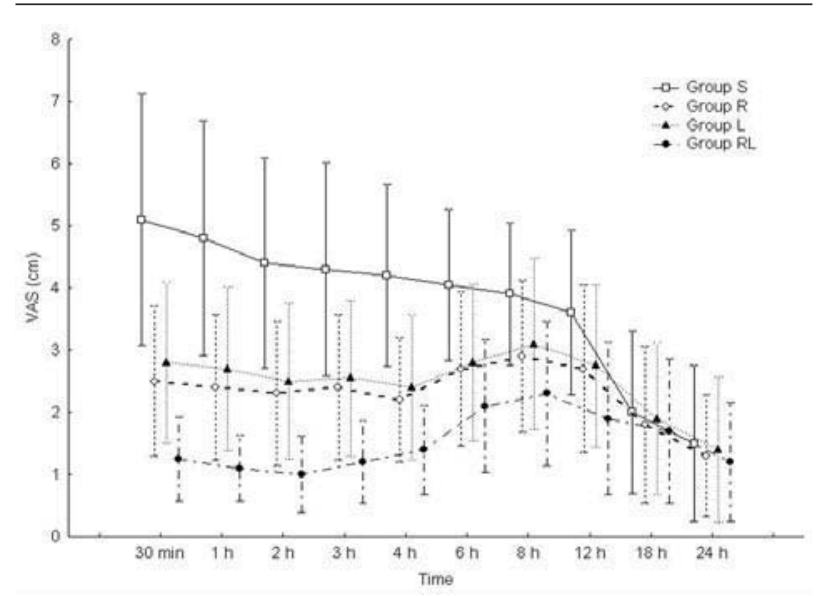

FIGURE I Visual analogue scale (VAS) pain scores during the first $24 \mathrm{hr}$ after surgery. Values are mean \pm standard deviation. Pain scores during the first $12 \mathrm{hr}$ postoperatively were significantly $(P<0.01)$ lower in Group ropivacaine plus lornoxicam (RL) when compared with Group saline $(S)$. Pain scores were significantly lower in Group ropivacaine plus lornoxicam (RL) when compared with Group ropivacaine $(\mathrm{R})$ and lornoxicam $(\mathrm{L})$ during the first four hours postoperatively $(P<0.01)$. Pain scores were significantly lower in Groups ropivacaine $(\mathrm{R})$ and lornoxicam $(\mathrm{L})$ when compared with Group saline ( $S$ ) during the first six and eight hours $(P<0.01, P<0.01 ; P<0.05, P<0.05$, respectively).

consumption did not differ significantly among the four study groups. However, the total meperidine consumption was significantly less in the Group RL compared with the Group $S(34.0 \pm 33.0 \mathrm{mg}$ vs 78.0 $\pm 29.8 \mathrm{mg} ; P<0.001$ ), (Figure 2). The time to first analgesic was also significantly longer in the Group RL compared with the Group S ( $14.8 \pm 8.4$ hr vs $5.9 \pm 5.2$ hr, $P<0.01$ ), (Table II). The return of bowel sounds, time of the first flatus and oral intake, and ambulation time were significantly faster in the Group RL compared with the Group S $(P<0.05$; Table II).

The most common adverse effect observed during the study were nausea, vomiting, abdominal discomfort, and dizziness (Table III). Incidence of PONV (Table III), and number of patients receiving antiemetics, and number of doses for patients receiving antiemetics were significantly $(P<0.05)$ less in Groups $\mathrm{RL}$ and $\mathrm{S}$ compared with Groups R and L; there was no difference in the incidence of other adverse effects among the groups (Table III). As shown in Table IV, more patients described their analgesia as good or excellent in Group RL than other groups $(P<0.01)$.

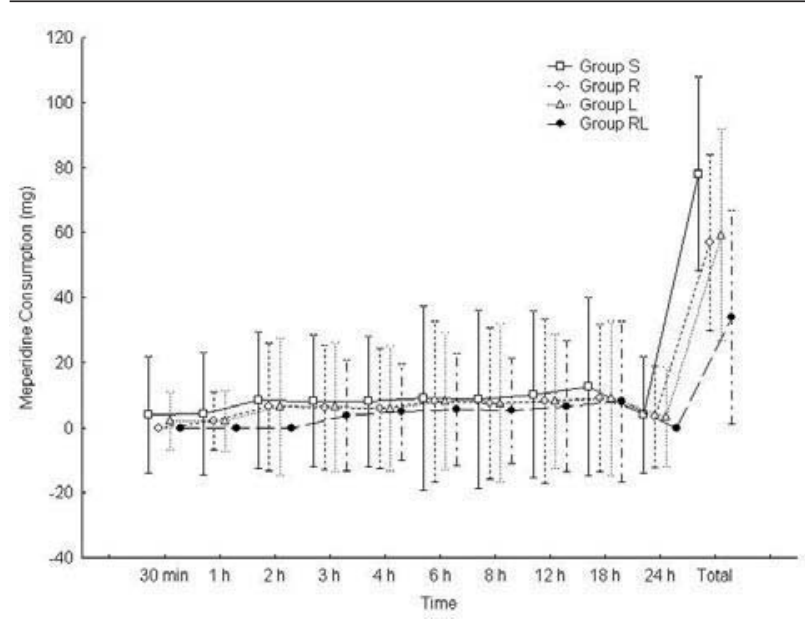

FIGURE 2 Meperidine consumption during the first 24 hr after surgery. Values are mean \pm standard deviation. The incremental meperidine consumption did not differ significantly among the four study groups. Total meperidine consumption was significantly less in Group ropivacaine plus lornoxicam (RL) when compared with Group saline $(S),(P$ $<0.001)$.

The LOS was significantly shorter in Group RL $(2 \pm$ 1 days) compared with the other groups ( $3 \pm 1$ days), $(P<0.05)$. The LOS was not significantly different among Groups R, L, and S (Table II). No patient experienced wound infection or delayed wound healing during their stay in hospital.

\section{Discussion}

Thyroid surgery induces postoperative discomfort caused by several mechanisms. Post-thyroidectomy pain perception likely includes components linked to the deep and superficial layers of the wound, intraoperative neck position and wound drainage. This pain may be treated with NSAIDs or opioids. ${ }^{1,2}$

Nonsteroidal anti-inflammatory drugs are commonly used analgesics for minor surgery and are useful adjunctive analgesics in patients undergoing major surgery, decreasing pain and opioid requirements. ${ }^{17}$ However, their use in some patients may be limited by adverse renal, gastrointestinal, and hematological effects. ${ }^{18}$ Opioids, although highly effective in managing pain, have a range of side effects such as respiratory depression, sedation, nausea, and vomiting. ${ }^{19}$

Lornoxicam is a potent new NSAID of the oxicam class. ${ }^{3,4}$ Previous studies with lornoxicam $8 \mathrm{mg}$ have shown it to be as effective as meperidine $50 \mathrm{mg}^{5}$ or 
TABLE II Postoperative outcome

\begin{tabular}{lllll}
\hline Variable & $\begin{array}{l}\text { Group } S \\
(n=20)\end{array}$ & $\begin{array}{l}\text { Group } R \\
(n=20)\end{array}$ & $\begin{array}{l}\text { Group } L \\
(n=20)\end{array}$ & $\begin{array}{l}\text { Group RL } \\
(n=20)\end{array}$ \\
\hline Time to first analgesic $(\mathrm{hr})$ & $5.9 \pm 5.2$ & $10.7 \pm 8.3$ & $11.1 \pm 7.7$ & $14.8 \pm 8.4 \dagger$ \\
Return of bowel sounds $(\mathrm{hr})$ & $9.6 \pm 2.5$ & $8.8 \pm 2.2$ & $9.0 \pm 2.2$ & $7.8 \pm 1.7^{*}$ \\
Time of the first flatus $(\mathrm{hr})$ & $14.7 \pm 3.1$ & $13.9 \pm 2.9$ & $14.1 \pm 2.8$ & $2.2 \pm 2.7^{*}$ \\
Oral intake $(\mathrm{hr})$ & $10.3 \pm 2.2$ & $9.4 \pm 2.2$ & $9.6 \pm 2.1$ & $8.5 \pm 1.9^{*}$ \\
Ambulation (hr) & $13.0 \pm 2.2$ & $12.0 \pm 2.0$ & $12.2 \pm 2.1$ & $11.2 \pm 2.0^{*}$ \\
Duration of hospital stay (days) & $3 \pm 1$ & $3 \pm 1$ & $3 \pm 1$ & $2 \pm 1 \ddagger$ \\
\hline
\end{tabular}

Group $\mathrm{S}=12 \mathrm{~mL}$ saline; Group $\mathrm{R}=10 \mathrm{~mL}$ of ropivacaine $0.75 \%$ plus $2 \mathrm{~mL}$ saline; Group $\mathrm{L}=2 \mathrm{~mL}$ of lornoxicam $(8 \mathrm{mg})$ plus $10 \mathrm{~mL}$ saline; Group $\mathrm{RL}=10 \mathrm{~mL}$ ropivacaine $0.75 \%$ plus $2 \mathrm{~mL}$ lornoxicam $(8 \mathrm{mg})$. Values are mean $\pm \mathrm{SD} .{ }^{*} P<0.05, \dagger P<0.01$ vs Group $\mathrm{S}$; $\ddagger P<0.05$ ps the other groups.

TABLE III Adverse effects

\begin{tabular}{|c|c|c|c|c|}
\hline Variable & $\begin{array}{l}\text { Group } S \\
(n=20)\end{array}$ & $\begin{array}{l}\text { Group R } \\
(n=20)\end{array}$ & $\begin{array}{l}\text { Group L } \\
(n=20)\end{array}$ & $\begin{array}{l}\text { Group } R L \\
(n=20)\end{array}$ \\
\hline Nausea & $7(35 \%)$ & $11(55 \%)$ & $11(55 \%)$ & $8(40 \%)$ \\
\hline Vomiting & $4(20 \%)$ & $8(40 \%)$ & $8(40 \%)$ & $5(25 \%)$ \\
\hline Abdominal discomfort & $2(10 \%)$ & $2(10 \%)$ & $2(10 \%)$ & $2(10 \%)$ \\
\hline Dizziness & $1(5 \%)$ & $1(5 \%)$ & $1(5 \%)$ & $2(10 \%)$ \\
\hline Headache & $0(0 \%)$ & l $(5 \%)$ & $1(5 \%)$ & $1(5 \%)$ \\
\hline Urinary retention & $1(5 \%)$ & $0(0 \%)$ & $1(5 \%)$ & $0(0 \%)$ \\
\hline
\end{tabular}

TABLE IV Patient satisfaction

\begin{tabular}{|c|c|c|c|c|}
\hline & $\begin{array}{l}\text { Group S } \\
(n=20)\end{array}$ & $\begin{array}{l}\text { Group R } \\
(n=20)\end{array}$ & $\begin{array}{l}\text { Group L } \\
(n=20)\end{array}$ & $\begin{array}{l}\text { Group } R L \\
(n=20)\end{array}$ \\
\hline Excellent & $3(15 \%)$ & $5(25 \%)$ & $4(20 \%)$ & $8(40 \%)$ \\
\hline Good & $4(20 \%)$ & $6(30 \%)$ & $7(35 \%)$ & $9(45 \%)$ \\
\hline Satisfactory & $10(50 \%)$ & $8(40 \%)$ & $8(40 \%)$ & $3(15 \%)$ \\
\hline Poor & $3(15 \%)$ & $1(5 \%)$ & $1(5 \%)$ & $0(0 \%)$ \\
\hline \multicolumn{5}{|c|}{$\begin{array}{l}\text { Group } \mathrm{S}=12 \mathrm{~mL} \text { saline; Group } \mathrm{R}=10 \mathrm{~mL} \text { of ropivacaine } 0.75 \% \\
\text { plus } 2 \mathrm{~mL} \text { saline; Group } \mathrm{L}=2 \mathrm{~mL} \text { of lornoxicam }(8 \mathrm{mg}) \text { plus } \\
10 \mathrm{~mL} \text { saline; Group } \mathrm{RL}=10 \mathrm{~mL} \text { ropivacaine } 0.75 \% \mathrm{plus} 2 \mathrm{~mL} \\
\text { lornoxicam }(8 \mathrm{mg}) \text {. Values are number }(\mathrm{n}) \text { and percentages }(\%) \\
P<0.01 \text { ropivacaine plus lornoxicam }(\mathrm{RL}) \text { Group vs the other } \\
\text { groups (comparing excellent and good vs satisfactory and poor). }\end{array}$} \\
\hline
\end{tabular}

tramadol $50 \mathrm{mg}^{20}$ after various surgical procedures. In another study, Trampitsch et al. ${ }^{21}$ determined that lornoxicam administered preemptively appears to improve the quality of postoperative analgesia, and leads to reduced consumption of opioid analgesics postoperatively in patients undergoing gynecological operations.

Studies have demonstrated that wound infiltration with local anesthetics are effective for the management of postoperative pain. ${ }^{6,7}$ Infiltration with local anesthetic at operative sites can improve postoperative analgesia and reduce opioid requirements after different surgical procedures. ${ }^{6,7,22}$

Previous studies determined that postoperative analgesia using wound infiltration with ropivacaine $3.75 \%{ }^{23}$ or $7.5 \%,{ }^{7}$ leads to a significant reduction of VAS values and opioid consumption in patients undergoing major shoulder surgery. However, studies related with abdominal hysterectomy demonstrated that local anesthetic wound infiltration does not decrease postoperative opioid requirements or improve patient comfort. ${ }^{24,25}$

Local anesthetic wound infiltration may reduce post-thyroidectomy pain. Gozal et al. ${ }^{26}$ reported that bupivacaine infiltration in thyroid surgery markedly reduced opioid requirements. In another study, bupivacaine wound infiltration effectiveness was considered disappointing when compared with two opioid regimens. ${ }^{27}$

The analgesic efficacy of the lornoxicam-ropivacaine combination infiltrated into wound for thyroid surgery has not been assessed previously. Georgiadou et al. ${ }^{15}$ determined that wound infiltration with levobupivacaine $0.5 \%$ plus lornoxicam $8 \mathrm{mg}$ provided better postoperative pain relief and reduced analgesic 
requirement more than levobupivacaine alone after cholecystectomy. In another study, Visalyaputra et al. ${ }^{14}$ reported that time to first analgesic requirement and morphine requirement during the first six hours was significantly lower in the group using local infiltration with lornoxicam and ropivacaine combination when compared with $i v$ morphine alone after abdominal hysterectomy.

Our study demonstrated that postoperative wound infiltration with ropivacaine $0.75 \%$ plus lornoxicam $8 \mathrm{mg}$ effectively reduced postoperative pain scores during the first $12 \mathrm{hr}$ postoperatively $(P<0.01)$, compared with saline. Our data further indicate that ropivacaine $0.75 \%$ or lornoxicam alone are less effective than their combination. Patients infiltrated with ropivacaine $0.75 \%$ plus lornoxicam required less total opioid consumption in the first $24 \mathrm{hr}$ postoperatively compared to placebo. Additionally, we found that the time to first analgesic was significantly longer in the combination group than in the control group.

The short plasma half-life (three to five hours) of lornoxicam may provide advantages over other NSAIDs. ${ }^{4,28}$ In the postoperative setting, lornoxicam has been well tolerated, with a tolerability profile similar to diclofenac ${ }^{29}$ but superior to that of indomethacin. ${ }^{5}$ The most frequent adverse effects were dizziness, abdominal pain, headache, and vomiting. ${ }^{3-5}$

Postoperative nausea and vomiting after thyroid surgery is especially common, with previous studies reporting a rate of $51 \%$ to $76 \%$. $^{30-32}$ Similarly in our study, the most common adverse effect in the study groups were PONV, and we determined a decrease in adverse effects associated with opioid consumption in the combination group, demonstrating that a multimodal analgesic approach using adjunctive drugs reduces the need for opioid analgesic and decreases adverse effects. The incidence of PONV (65\% vs 95\%, respectively) and antiemetic requirements were less in the combination group and Group $S$ than in the R and L Groups $(P<0.05)$. We have no idea why the placebo group had a lower PONV incidence. Since sex and age were similar, other confounding factors such as history of PONV may be included. Unfortunately, we did not control for other factors. However, there were no significant differences among groups with respect to other adverse effects. A possible concern about this technique may be the potential risk of delayed wound healing and infection. ${ }^{31}$ Our study revealed no signs of local inflammation in any of the patients.

In our study, the return of gastrointestinal function and times to ambulation were significantly faster in Group RL compared with Group $S(P<0.05)$. We conclude that higher patient satisfaction in the combination group is a reflection of shortened time of return of gastrointestinal function and ambulation time. This is also clinically significant. Hospital LOS $(P<0.05)$ was shorter, and patient satisfaction was better in the combination group when compared with the other groups, without increasing the bleeding risk in Group RL compared with Group S. Patients treated with ropivacaine plus lornoxicam experience a more rapid return of gastrointestinal function, probably because of reductions in meperidine consumption.

The higher degree of patient satisfaction $(P<0.01)$ in the combination group compared with the other groups is further evidence in favour of the use of this technique for postoperative pain management. Early mobilization of patients after thyroid surgery is one of the most important surgical determinants for hospital discharge. ${ }^{22}$

In conclusion, wound infiltration with ropivacaine $0.75 \%$ plus lornoxicam $8 \mathrm{mg}$ administered postoperatively, provides better postoperative pain relief and patient comfort, and decreased opioid consumption compared with saline in patients undergoing thyroid surgery. When wound infiltration is planned in thyroid surgery a local anesthetic/NSAID combination provides a more favourable outcome than either drug alone.

\section{References}

1 Daou $R$. Thyroidectomy without drainage. Chirurgie 1997; 122: 408-10.

2 Dieudonne N, Gomola A, Bonnichon P, Ozier YM. Prevention of postoperative pain after thyroid surgery: a double-blind randomized study of bilateral superficial cervical plexus blocks. Anesth Analg 2001; 92: 153842.

3 Radhofer-Welte S, Rabasseda X. Lornoxicam, a new potent NSAID with an improved tolerability profile. Drugs Today 2000; 36: 55-76.

4 Balfour JA, Fitton A, Barradell LB. Lornoxicam. A review of its pharmacology and therapeutic potential in the management of painful and inflammatory conditions. Drugs 1996; 51: 639-57.

5 Rosenow DE, van Krieken F, Stolke D, Kursten FW. Intravenous administration of lornoxicam, a new NSAID, and pethidine for postoperative pain. A placebo-controlled pilot study. Clin Drug Invest 1996; 11: 11-9.

6 Bianconi M, Ferraro L, Ricci R, et al. The pharmacokinetics and efficacy of ropivacaine continuous wound instillation after spine fusion surgery. Anesth Analg 2004; 98: 166-72.

7 Horn EP, Schroeder F, Wilhelm S, et al. Wound infiltration and drain lavage with ropivacaine after major 
shoulder surgery. Anesth Analg 1999; 89: 1461-6.

8 Hannibal K, Galatius H, Hansen A, Obel E, Ejlersen

$E$. Preoperative wound infiltration with bupivacaine reduces early and late opioid requirement after hysterectomy. Anesth Analg 1996; 83: 376-81.

9 Dierking $G W$, Ostergaard E, Ostergard HT, Dahl JB. The effects of wound infiltration with bupivacaine versus saline on postoperative pain and opioid requirements after herniorrhaphy. Acta Anaesthesiol Scand 1994; 38: 289-92.

10 Sztark F, Malgat M, Dabadie P, Mazat JP. Comparison of the effects of bupivacaine and ropivacaine on heart cell mitochondrial bioenergetics. Anesthesiology 1998; 88: 1340-9.

11 Scott DB, Lee A, Fagan D, Bowler GM, Bloomfield P, Lundh $R$. Acute toxicity of ropivacaine compared with that of bupivacaine. Anesth Analg 1989; 69: 563-9.

12 Kopacz DJ, Carpenter RL, Mackey DC. Effect of ropivacaine on cutaneous capillary blood flow in pigs. Anesthesiology 1989; 71: 69-74.

13 Martinsson T, Oda T, Fernvik E, Roempke K, Dalsgaard CJ, Svensjo E. Ropivacaine inhibits leukocyte rolling, adhesion and CD11b/CD18 expression. J Pharmacol Exp Ther 1997; 283: 59-65.

14 Visalyaputra S, Sanansilp V, Pechpaisit N, et al. Postoperative analgesic effects of intravenous lornoxicam and morphine with pre-emptive ropivacaine skin infiltration and preperitoneal instillation after transabdominal hysterectomy. J Med Assoc Thai 2002; 85(Suppl 3): S1010-6.

15 Georgiadou TH, Sfyra E, Georgiou M, Foulidou A, Papaioannou V, Kanakoudis F. Postoperative wound infiltration with chirocaine plus lornoxicam for pain relief after cholecystectomy. Eur J Anaesthesiol 2003; 20(Suppl 30): A-689 (abstract).

16 Jorgensen H, Fomsgaard JS, Dirks J, Wetterslev J, Andreasson B, Dabl JB. Effect of peri- and postoperative epidural anaesthesia on pain and gastrointestinal function after abdominal hysterectomy. Br J Anaesth 2001; 87: 577-83.

17 Scott RM, Jennings PN. Rectal diclofenac analgesia after abdominal hysterectomy. Aust NZ J Obstet Gynaecol 1997; 37: 112-4.

18 Kam PC, Power I. New selective COX-2 inhibitors. Pain Reviews 2000; 7: 3-13.

19 Fishman S, Borsook D. Opioids in pain management. In: Benzon H, Raja S, Molloy RE, Strichartz G (Eds). Essentials of Pain Medicine and Regional Anesthesia. New York: Churchill Livingstone; 1999: 51-4.

20 Ilias $W$, Jansen $M$. Pain control after hysterectomy: an observer-blind, randomised trial of lornoxicam versus tramadol. Br J Clin Pract 1996; 50: 197-202.

21 Trampitsch E, Pipam W, Moertl M, et al. Preemptive randomized, double-blind study with lornoxicam in gynecological surgery (German). Schmerz 2003; 17: 4-10.

22 Bianconi $M$, Ferraro L, Traina GC, et al. Pharmacokinetics and efficacy of ropivacaine continuous wound instillation after joint replacement surgery. Br J Anaesth 2003; 91: 830-5.

23 Gottschalk A, Burmeister MA, Radtke P, et al. Continuous wound infiltration with ropivacaine reduces pain and analgesic requirement after shoulder surgery. Anesth Analg 2003; 97: 1086-91.

24 Klein JR, Heaton JP, Thompson JP, Cotton BR, Davidson AC, Smith G. Infiltration of the abdominal wall with local anaesthetic after total abdominal hysterectomy has no opioid-sparing effect. Br J Anaesth 2000; 84: 248-9.

25 Cobby TF, Reid MF. Wound infiltration with local anaesthetic after abdominal hysterectomy. Br J Anaesth 1997; 78: 431-2.

26 Gozal Y, Shapira SC, Gozal D, Magora F. Bupivacaine wound infiltration in thyroid surgery reduces postoperative pain and opioid demand. Acta Anaesthesiol Scand 1994; 38: 813-5.

27 Lacoste L, Thomas D, Kraimps JL, et al. Postthyroidectomy analgesia: morphine, buprenorphine, or bupivacaine? J Clin Anesth 1997; 9: 189-93.

28 Staunstrup H, Ovesen J, Larsen UT, Elbaek K, Larsen $U$, Kroner $K$. Efficacy and tolerability of lornoxicam versus tramadol in postoperative pain. J Clin Pharmacol 1999; 39: 1-8.

29 Rosenow DE, Albrechtsen M, Stolke D. A comparison of patient-controlled analgesia with lornoxicam versus morphine in patients undergoing lumbar disk surgery. Anesth Analg 1998; 86: 1045-50.

30 Watcha MF, White PF. Postoperative nausea and vomiting. Its etiology, treatment, and prevention. Anesthesiology 1992; 77: 162-84.

31 Wang JJ, Ho ST, Lee SC, Liu $\Upsilon$ C, Ho CM. The use of dexamethasone for preventing postoperative nausea and vomiting in females undergoing thyroidectomy: a dose-ranging study. Anesth Analg 2000; 91: 1404-7.

32 Wang JJ, Ho ST, Lee SC, Liu YC, Liu YH, Liao YC. The prophylactic effect of dexamethasone on postoperative nausea and vomiting in women undergoing thyroidectomy: a comparison of droperidol with saline. Anesth Analg 1999; 89: 200-3. 